\title{
DISTRIBUSI PENDAPATAN PETANI KARET DI KECAMATAN BAJUBANG KABUPATEN BATANGHARI
}

\author{
Dwi Nurul Amalia1) \\ Dosen Jurusan Agribisnis Fakultas Pertanian Universitas Jambi \\ Email : dwinurulamalia@unja.ac.id
}

\begin{abstract}
ABSTRAK
Penelitian ini bertujuan untuk (1) Menganalisis tingkat pendapatan usahatani karet dan perbedaan pendapatan usahatani karet yang memasarkan bokar di pasar lelang dan non pasar lelang (2) Menganalisis tingkat pendapatan petani karet dan perbedaan pendapatan petani karet yang memasarkan bokar di pasar lelang dan non pasar lelang (3) ketimpangan distribusi pendapatan utama usahtani karet dan pendapatan petani karet yang memasarkan bokar di pasar lelang dan non pasar lelang. Jumlah Sampel sebanyak 70 petani yang terdiri dari 34 petani yang menjual ke pasar lelang dan 36 petani yang menjual ke non pasar lelang.Berdasarkan hasil uji beda dua rata rata terdapat perbedaan pendapatan utama usahatani karet yang menjual bahan olah karet ke pasar lelang Nilai indeks gini satu kawasan yaitu 0,29 berada pada ketimpangan rendah $<0,32$ berada pada ketimpangan sedang, dan nilai indeks gini pasar lelang 0,27 dan non pasar lelang 0,24 0,26 berada pada ketimpangan rendah pendapatan terdistribusi merata.
\end{abstract}

Kata Kunci : Karet, Pasar Lelang, Non Pasar lelang, Karet, Pendapatan

\begin{abstract}
This research aims to (1) analyze the main income level of rubber farming and the major revenue difference of rubber farming that markets Bokar in auction market and non Auction market (2) analyzing the income levels of rubber farmers and the difference rubber farmer's income that markets Bokar in auction market and non Auction market (3) Inequality of major income distribution of rubber farming and rubber farmer income that markets Bokar in auction market and non auction market. The number of samples was 70 Peani consisting of 34 farmers who sold to auction market and 36 farmers who sold to non auction markets. Based on the results of the two average difference there is a major income difference rubber farming that sells rubber materials to the auction market is smaller than the value of $<\alpha=5 \%$. With the value of a one-area Gini index of 0.29 being at the low inequality of $<0.32$ is at moderate inequality, and the value of the auction market Gini index 0.27 and non auction market $0.24>0.26$ are at low inequality of evenly distributed revenues.
\end{abstract}

Keywords: Auction market, Income, Rubber, Non Market Auction.

\section{PENDAHULUAN}

Sektor pertanian merupakan sektor yang penting dalam memacu pertumbuhan dan pembangunan ekonomi masyarakat Indonesia. Sektor pertanian memegang peranan penting bagi perekonomian Indonesia. Hal tersebut didasarkan pada peranannya sebagai penyedia bahan pangan, bahan baku Industri, sumber pendapatan bagi jutaan petani yang tersebar diseluruh Indonesia, serta sebagai penghasil devisa negara setelah sektor minyak dan gas (BPS Republik Indonesia, 2017). Pembangunan subsektor perkebunan secara garis besar mempunyai tujuan untuk meningkatkan produksi dan pendapatan masyarakat yang dihadapkan berbagai tantangan pembangunan pertanian dimasa mendatang yang kompleks, seperti penambahan jumlah penduduk yang setiap tahunnya terjadi cukup besar (Direktorat Jendral Perkebunan, 2017). Selain untuk menciptakan pertumbuhan, pembangunan ekonomi juga bertujuan untuk meningkatkan pemerataan, dengan kata lain, peningkatan pendapatan dapat terdistribusi diseluruh kalangan bukan hanya dinikmati sekelompok 
masyarakat saja, sehingga dengan adanya pembangunan pertanian diharapkan para petani dapat sejahtera (Todaro,2003).

Provinsi Jambi merupakan Sall9ah satu Provinsi penyumbang komoditi perkebunan di Indonesia dan memiliki potensi sumberdaya alam yang baik untuk usaha atau kegiatan di sektor perkebunan. Kabupaten Batanghari merupakan salah satu kabupaten yang ada di Provinsi Jambi, terlihat gambaran ekonomi umumnya didominasi pada sektor petanian terutama sub sektor perkebunan. Dari total areal perkebunan karet merupakan lahan terluas, dapat dimaklumi mengapa pentingnya komoditas karet ini sebagai salah satu komoditi utama Kabupaten Batanghari. Kecamatan Bajubang merupakan salah satu daerah dengan luas areal dan produksi terbesar kedua dari delapan kecamatan dengan luas areal tanaman menghasilkan $16.920 \mathrm{Ha}$, dengan total luas areal sebesar $22,979 \mathrm{Ha}$ atau berkontribusi sebesar 20,3\% dan jumlah produksi sebesar 16.402 ton atau sebesar $22 \%$ dari total jumlah luas areal dan produksi yang ada di Kabupaten Batanghari, sedangkan produktivitasnya tertinggi sebesar $969 \mathrm{Kg} / \mathrm{Ha}$ atau sebesar $12,9 \%$.

Seiring meningkatnya jumlah lahan, produksi dan banyaknya jumlah petani yang bergerak dibidang perkebunan karet harusnya dapat meningkatkan pendapatan petani. Akan tetapi perubahan harga karet yang sangat fluktuatif dan dapat terjadi kapan saja. Membuat pendapatan petani rendah, telah terjadi perubahan harga yang sangat signifikan pada tahun 2011 hingga tahun 2017. Pada tahun 2011 harga karet di Kabupaten Batanghari mencapai Rp. 17.500/kg, kemudian terus menurun hingga mencapai Rp.8.000/kg ( Dinas Perkebunan Provinsi Jambi,2017). Hal ini tentu akan berdampak pada pendapatan petani yang menurun ditambah dengan informasi dari penyuluh bahwa penetapan harga pada tingkat petani yang masih terdapat perbedaan. Berdasarkan survei lapangan Pemasaran karet Di Kecamatan Bajubang terdapat dua saluran pemasaran (tataniaga) yaitu petani menjual karetnya melalui saluran pemasaran pasar lelang karet di Desa Penerokan yaitu melalui pengawasan pengurus lembaga KUD Berdikari dan yang menjual ke non pasar lelang. Desa Penerokan merupakan salah satu desa yang terdapat di Kecamatan Bajubang yang memiliki luas lahan dan produksi yang paling besar dan disusul dengan Ladang Peris.

Salah satu masalah yang terdapat pada komoditi perkebunan karet yaitu pemasaran hasil kebun di kecamatan tersebut yang masih belum baik., dimana petani yang menjual ke pasar lelang lebih sedikit dibandingkan petani yang menjual ke non pasar lelang tanpa prantara dan pengawasan KUD (Koperasi Berdikari 2019), dimana petani yang menjual ke pasar lelang lebih sedikit dibandingkan petani yang menjual ke non pasar lelang tanpa prantara dan pengawasan KUD (Koperasi Berdikari 2019). kelembagaan koperasi yang dibentuk ini atas dasar kepentingan bersama karena diketahui bahwa harga jual melalui pasar lelang dengan perantara koperasi unit desa dan ke non pasar lelang memiliki perbedaan. Fenomena diatas bahwa ada dua saluran pemasaran karet petani yaitu melalui pasar lelang dan non pasar lelang diKecamatan Bajubang. Tujuan pembentukan pasar lelang ialah untuk meningkatkan pendapatan dan kesejahteraan petani karet. Keunggulan pasar lelang adalah : (1). Harga pasar lelang lebih terbuka, (2). Penilaian mutu atau penetapan KKK oleh tim, (3). Harga berdasarkan mutu (KKK) . Harga pada non pasar lelang ditentukan berdasarkan taksiran pedagang melalui pengamatan secara visual hanya berdasarkan kebiasaan pedagang karena petani dan pedagang sudah memiliki ikatan familly. Perbedaan produksi dan mutu antara petani pada masingmasing desa terutama kedua Desa Penerokan dan Ladang Peris merupakan faktor perbedaan penerimaan dan pendapatan petani.

Proses pemasaran bokar yang melalui pasar lelang dilakukan setiap dua minggu sekali, dalam proses tersebut masing-masing petani membawa bokarnya ketempat pengumpulan bokar, standar karet kering (KKK) yang ditetapkan oleh pasar lelang biasanya yaitu $51-60 \%$. Sehingga dalam hal ini terdapat peran dari pasar lelang itu sendiri yaitu untuk meningkatkan mutu bokar melalui ketentuan ketentuan yang berlaku. Pada wilayah Kecamatan Bajubang komoditi karet produksi dalam bentuk bokar (slab) merupakan sumber penghasil utama bagi petani. Sebagian besar petani menjual bokar pada umumnya berdasarkan bobot karet bukan berdasarkan mutu atau KKK. Karena mengharap berat bokar lebih besar maka petani melakukan perendaman, mencampur lateks dengan tatal,pasir atau benda-benda lain sebagai penambah berat meskipun mutu rendah biasanya petani seperti itu akan menjual karetnya ke non pasar lelang di Desa tersebut dengan tingkat harga yang rendah dengan harga yang tidak transparan.

Berdasarkan informasi dari penyuluh dilapangan dimana harga jual karet melalui pasar lelang lebih tinggi dibandingkan dengan harga jual karet di non pasar lelang tanpa adanya pengawasan karena 
informasi harga karet yang di terima melalui pasar lelang dengan pengawasan koperasi berdasarkan harga rata-rata karet menurut Singapore commudity exchangedan indeks harga juga digunakan digunakan harga acuan Gapkindo. harga yang disajikan tersebut adalah harga kadar karet kering 100 persen yang menjadi acuan petani dalam menghitung harga karet yang diterima, pada saluran pemasaran melalui non pasar lelang kualitas bokar petani yang baik atau tidak baik tetap dibeli dengan harga yang rendah yang telah ditetapkan sesuai kesepakatan. Jika penjualan melalui non pasar lelang di desa-desa tidak memperhatikan kualitas karet yang dihasilkan petani, hanya mengandalkan perkiraan mutu karet pada saat menentukan harga karet, dengan adanya perbedaan produksi,mutu serta harga antar petani sehingga pendapatan yang diterima petani pasti akan berbeda ditambah dengan harga karet yang tidak menentu, jumlah tanggungan yang berbeda dengan demikian petani membutuhkan penghasilan dari sumber lainnya demi memenuhi kebutuhan hidup dengan sumber pendapatan yang berbeda-beda maka akan terjadi ketimpangan pendapatan (distribusi prndapatan).

Berdasarkan latar belakang dan permasalahan yang dikemukakan, maka penelitian ini bertujuan: (1) Menganalisis tingkat pendapatan utama usahatani karet dan perbedaan pendapatan utama usahatani karet yang memasarkan bokar di pasar lelang dan non pasar lelang (2) Menganalisis tingkat pendapatan petani karet dan perbedaan pendapatan petani karet yang memasarkan bokar di pasar lelang dan non pasar lelang (3) ketimpangan distribusi pendapatan utama usahtani karet dan pendapatan petani karet yang memasarkan bokar di pasar lelang dan non pasar lelang.

\section{METODE PENELITIAN}

Penelitian ini dilakukan di Kecamatan Bajubang Kabupaten Batanghari. Daerah penelitian ini dipilih secara sengaja (purposive) dengan pertimbangan bahwa Kecamatan Bajubang memiliki produktivitas dan produksi tertinggi di Kabupaten Batanghariserta dengan pertimbangan bahwa di Kecamatan Bajubang petani menjual bahan olah karet ke pasar lelang dan non pasar lelang terdapat dua desa yang menjual bahan olah karet ke pasar lelang dan non pasar lelang di kecamatan bajubang yaitu Desa Penerokan dan Desa Ladang. Data yang dikumpulkan dalam penelitian ini meliputi data Primer dan data sekunder. Data primer merupakan data yang secara langsung diperoleh dilapangan. Sedangkan data sekunder Didapat dari instansi pemerintah yang terkait yaitu Dinas Perkebunan Kebupaten Batanghari, Dinas, Badan Pusat Statistik Kabupaten Muaro Jambi, Kantor Camat Penerokan dan Lading Peris, laporan penelitian dan instansi lain yang terkati terhadap penelitian ini.

Berdasarkan informasi untuk jumlah populasi petani karet pemilik penyadap (penggarap) di Desa Penerokan dan Ladang Perissebanyak 2.529 KK dimana untuk desa penerokan $1.573 \mathrm{KK}$ dan Ladang Peris $956 \mathrm{KK}$..Teknik pengambilan sample menggunakan rumus dari Taro Yamane atau Slovin. Penarikan sampel (responden) didasarkan pada penarikan sampel minimal 12 persen, hal ini sesuai dengan pendapat Taro Yamane atau lebih dikenal dengan nama metode Slovin. Populasi dalam penelitian ini adalah petani yang menjual karet dalam bentuk bokar (Slab Tebal) ke pasar lelang dan non pasar lelang setiap dua minggu sekali. Jumlah sampel yaitu 70 sampel dari Desa Peneroka sebanyak 34 dan Desa Ladang Peris sebanyak 36. Teknik pengambilan sampel dalam penelitian ini . Penelitian ini difokuskan pada petani pemilik penggarap yang berusahatani karet sebagai tanaman utama serta seluruh pendapatan keluarga petani pada kegiatan on farm, off farm dan non farm dan yang akan diteliti adalah perbedaan pendapata usahatani karet yang menjual bahan olah karet (bokar) dalam bentuk slabke pasar lelang dan non pasar lelang dan distribusi ( ketimpangan pendapatan) dengan analisis indeks gini rasio terhadap total pendapatan rumah tangga petani. Data yang diperoleh secara tabulasi dalam penelitian ini untuk menganalisis pendapatan secara matematis digunakan rumus sebagai berikut:

Keterangan :

$$
\mathrm{Pd}=\mathrm{TR}-\mathrm{TC}
$$

$\mathrm{Pd}=$ Pendapatan Usahatani Karet $(\mathrm{Rp} / \mathrm{tahun})$

TR $=$ Total Penerimaan pada Usahatani Karet (Total Revenue) (Rp/tahun)

TC $=$ Total Biaya Produksi (Total Cost) (Rp/tahun)

Selain itu untuk mengetahui apakah terdapat perbedaan tingkat pendapatan utama usahatani karet dan pendapatan petani karet secara nyata petani yang menjual pada pasar lelang dan yang 
menjual dinonpasar lelang. Dilakukan pengujian dengan menggunakan uji beda dua rata-rata dengan rumus:

$t_{\text {hit }}=\frac{\boldsymbol{X}_{\mathbf{1}}-\boldsymbol{X}_{\mathbf{2}}}{\operatorname{Se} \sqrt{\frac{1}{\frac{1}{n_{1}}+\frac{1}{n_{2}}}}}$

Dimana:

$$
S e \sqrt{(n-1) S_{1}^{2}+\left(n_{2}-1\right) S_{2}^{2}}
$$

$$
\begin{aligned}
& \mathrm{X}_{1}=\text { Rata-rata pendapatan petani karet yang menjual ke Pasar Lelang }(\mathrm{Rp}) \\
& \mathrm{X}_{2}=\text { Rata-rata pendapatan petani karet yang menjual ke Non Pasar Lelang(Rp) } \\
& \mathrm{n}_{1}=\text { Jumlah sampel petani karet yang menjual ke pasar lelang (orang) } \\
& \mathrm{n}_{2}=\text { Jumlah sampel petani karet yang menjual ke non pasar lelang(orang) } \\
& \boldsymbol{S}_{1}^{2}=\text { Varians dari sampel petani menjual ke pasar lelang } \\
& S_{2}^{2}=\text { Varians dari sampel petani menjual ke non pasar lelang } \\
& \mathrm{Se}=\text { Standar deviasi }
\end{aligned}
$$

Pendapatan rumah tangga diperoleh dengan cara menjumlahkan pendapatan keluarga yang berasal dari usahatani dan pendapatan keluarga yang berasal dari luar usahatani, dihitung dengan rumus sebagai berikut (Hastuti, 2008) :

Keterangan :

$$
\text { Prt }=\mathrm{P}_{\text {on farm }}+\mathrm{P}_{\text {off farm }}+\mathrm{P}_{\text {non farm }}
$$

$$
\begin{array}{ll}
\text { Prt } & \text { = Pendapatan Rumah Tangga Petani/Tahun } \\
\mathrm{P}_{\text {on farm }} & =\text { Pendapatan dari Usahatani Karet/Tahun } \\
\mathrm{P}_{\text {off farm }} & =\text { Pendapatan dari Luar Usahatani Karet/Tahun } \\
\mathrm{P}_{\text {non Farm }} & \text { = Pendapatan dari Luar Pertanian/Tahun }
\end{array}
$$

Selanjutnya untuk melihat Distribusi atau ketimpangan pendapatan dianalisis menggunakan alat analisis penghitungan indeks Gini (Widodo, 1990). Analisis Indeks Gini Rasio dipakai untuk mendapati ketimpangan pendapatan petani karet yang menjual ke pasar lelang dan non lelang.

Dimana:

$$
\mathrm{GR}=1-\Sigma . f \mathrm{i}(\mathrm{Xi}+1+\mathrm{Xi})(\mathrm{Yi}+1+\mathrm{Yi})
$$

GR : Angka koefisien gini

$\mathrm{Xi}$ : Proporsi jumlah rumah tangga kumulatif dalam kelas ke-i

$\mathrm{Fi}$ : Proporsi jumlah rumah tangga dalam kelas ke-i

Yi : Proporsi jumlah pendapatan kumulatif dalam kelas ke-i

Kriteria ketimpangan distribusi pendapatan Gini Ratio menurut Widodo (1990) adalah:

1. Angka Gini < 0,3 merupakan ketimpangan rendah atau ringan

2. Angka Gini 0,3-0,4 merupakan ketimpangan sedang

3. Angka Gini $\geq 0,4$ merupakan ketimpangan berat.

\section{HASIL DAN PEMBAHASAN}

\section{Karateristik Petani}

Umur merupakan salah satu factor penting dalam kegiatan berusahatani karena pada umumnya akan berkaitan dengan kondisi fisik maupun mental yang akan berpengaruh terhadap kemampuan seseorang. Hasil penelitian terhadap umur petani didaerah penelitian bervariasi, dimana umur petani responden yang menjual bahan olah karet ke pasar lelang dan non lelang berkisar antara 20 sampai 69 tahun dengan rata-rata umur 50 tahun Menurut Tuo (2011) bahwa usia produktif dalam usahatani berkisar 15-55 tahun. Ini berarti para petani mempunyai kemampuan untuk bekerja lebih maksimal untuk mengelola usahataninya. pendidikan merupakan salah satu factor yang mempengaruhi pola pikir seseorang dalam menentukan pilihan serta memilih keputusan yang tepat bagi kepentingannya. Pendidikan pada umumnya berpengaruh pada cara berpikir petani yang akan melaksanakan kegiatan usahataninya. Menurit Hernanto (1996) keterbatasan tingkat pendidikan akan mempengaruhi cara berfikir, menerima ataupun menolak hal-hal baru. 
Jumlah Tanggungan keluarga adalah semua orang yang tinggal dalam satu rumah dan menjadi tanggungan petani sebagai kepala keluarga. Bnyaknya anggota keluarga tentu akan berkaitan dengan penggunaan pendapatan terutama dalam hal pemenuhan kebutuhan dasar. Semakin banyak jumlah anggota keluarga maka semakin besar kebutuhan yang harus dipenuhi. Apabila penambahan anggota keluarga tidak diikuti dengan peningkatan pendapatan, maka akan menyebabkan kesejahteraan tidak tercapai, bahwa jumlah tanggungan keluarga petani sampel terbanyak adalah pada sebaran 3 orang tanggungan. Pengalaman usahatani merupakan lamanya pengalaman kerja petani dalam menjalankan kegiatan usahataninya. Petani yang berpengalaman dalam usahatani akan terlihat lebih terampil dalam mengelola usahatani. Menurut Hernanto (1996) pengalaman berusahatani termasuk factor yang paling menentukan keberhasilan suatu usaha karena bermanfaat untuk digunakan dalam pertimbangan usaha dan pengambil keputusan pada proses produksi, pengelolaan dan pemasaran hasil. Menunjukan bahwa petani sampel yang menjual bahan olah karet ke pasar lelang dan non pasar lelang memiliki sebaran terbesar pengalaman berusahatani pada kisaran 20-29 tahun. Lahan adalah sumberdaya alam fisik yang mempunyai peran penting dalam segala kehidupan manusia karena diperlukan manusia untuk tenpat tinggal hidup, kemudian untuk melakukan kegiatan pertanian, perikanan, peternakan, kehutanan, pertambangan dan seterusnya.

Menurut Suratiyah (2015) semakin luas lahan yang diusahakan maka semakin tinggi produksi dan pendapatan per satuan luasnya. Petani yang memiliki lahan yang luas akan berproduksi tinggi apabila dikelola secara baik, begitu juga sebaliknya petani yang mempunyai lahan sempit akan berproduksi sedikit ditambah lahi jika tidak dikelola dengan baik. Luas lahan karet yang diusahakan petani di daerah penelitian ini adalah luas lahan karet yang dimiliki sendiri. Berdasarkan hasil penelitian, petani yang melakukan penjualan bahan olah karet ke pasar lelang memiliki rata-rata luas lahan yaitu $3,4 \mathrm{Ha}$, sedangkan untuk petani yamg menjual bahan olah karet ke non lelang yaitu dengan rata-rata luas lahan $3,1 \mathrm{Ha}$. Adapun distribusi berdasarkan luas lahan yang dimiliki petani didaerah penelitian dapat dilihat pada Tabel 1.

Tabel 1. Distribusi Frekuensi Kepemilikan Lahan Utama Usahatani karet Petani Sampel di Daerah Penelitian Tahun 2019

\begin{tabular}{crrrr}
\hline Luas Lahan & \multicolumn{2}{c}{ Pasar Lelang } & \multicolumn{2}{c}{ Non Pasar Lelang } \\
\cline { 2 - 5 }$(\mathrm{Ha})$ & \multicolumn{1}{c}{ Frekuensi } & Persentase (\%) & Frekuensi & Persentase(\%) \\
\hline $2 \leq 4$ & 22 & 64,7 & 26 & 72,2 \\
$4 \leq 6$ & 8 & 23,5 & 8 & 22,2 \\
$6 \leq 8$ & 3 & 8,8 & 2 & 5,6 \\
$8 \leq 10$ & 1 & 2,9 & 0 & 0 \\
\hline Jumlah & $\mathbf{3 4}$ & $\mathbf{1 0 0}$ & $\mathbf{3 6}$ & $\mathbf{1 0 0}$ \\
\hline
\end{tabular}

Sumber: Olahan Data Primer (2019)

Tabel 1 memperlihatkan luas lahan garapan petani bervariasi mulai dari petani yang memiliki luas lahan $2 \mathrm{Ha}$ hingga petani yang memiliki luas lahan $10 \mathrm{Ha}$. Luas lahan terbanyak yang dimiliki petani responden didaerah penelitian yaitu pada kisaran luas lahan $2<3 \mathrm{Ha}$ untuk petani yang menjual bahan olah karet ke pasar lelang sebanyak 22 orang atau $64,7 \%$ sedangkan sebaran luas lahan terendah pada kisaran 8-10 $\mathrm{Ha}$ dengan jumlah petani 1 orang atau 2,9\% sementara untuk petani yang menjual bahan olah karet ke non pasar lelang terbanyak pada sebaran $2<3$ Ha dengan jumlah petani 26 orang atau $72,2 \%$ dan sebaran terendah pada kisaran 6-10 Ha dengan jumlah petani 2 orang atau $5,6 \%$. Sebagian besar petani karet tidak hanya memiliki lahan karet saja melainkan terdapat lahan usahatani lainnya seperti sawit dan jagung, untuk lebih jelasnya berikut uraian luas lahan yang dimiliki petani karet diluar luas lahan karet.

Tabel 2. Distribusi Petani Sampel berdasarkan luas lahan yang dimiliki diluar lahan karet di Daerah Penelitian Tahun 2019

\begin{tabular}{crrrr}
\hline Luas Lahan & \multicolumn{2}{c}{ Pasar Lelang } & \multicolumn{2}{c}{ Non Pasar Lelang } \\
\cline { 2 - 5 }$(\mathbf{H a})$ & \multicolumn{1}{c}{ Frekuensi } & Persentase(\%) & Frekuensi & Persentase(\%) \\
\hline $5 \leq 1,5$ & 2 & 25 & 2 & 22,2 \\
$1,5 \leq 2,5$ & 4 & 50 & 5 & 55,6 \\
$2,5 \leq 3,5$ & 2 & 25 & 2 & 22,2 \\
\hline Jumlah & $\mathbf{8}$ & $\mathbf{1 0 0}$ & $\mathbf{9}$ & $\mathbf{1 0 0}$ \\
\hline
\end{tabular}

Sumber: Olahan Data Primer (2019) 
Tabel 2 menunjukkan bahwa luas lahan yang dimiliki petani diluar luas lahan karet cukup bervariasi , luas lahan yang jumlah petaninya terbanyak terdapat pada kelompok $1,5<2 \mathrm{Ha}$ yaitu untuk petani yang menjual bahan olah karet ke pasar lelang $50 \%$ sedangkan petani yang menjual ke non pasar lelang sebesar $55,6 \%$. Rata-rata luas lahan usahatani petani diluar lahan karet yaitu seluas $2 \mathrm{Ha}$.

\section{Sumber Mata Pencaharian}

Sebagian petani di daerah penelitian melakukan berbagai macam usaha (kombinasi usaha) karena dengan melakukan banyak usaha dapat memperkecil resiko kegagalan usahatani dan juga mampu memberikan tambahan pendapatan terhapat petani agar terpenuhinya kebutuhan dasar.Sumber penghasilan petani karet terdiri dari bermacam-macam sumber pendapatan. Sumber-sumber pendapatan inilah yang diperoleh petani untuk dapat memenuhi kebutuhan dalam rumahtangganya. Sebagaimana diketahui bahwa pendapatan rumah tangga tidak berasal dari satu sumber, tetapi berasal dari dua atau lebih sumber pendapatan untuk memenuhi kebutuhan hidup. Dalam melakukan berbagai macam cabang usahatani dikarenakan harga karet yang tidak menentu (Fluktuatif) ditambah harga yang didapat setiap petadi berbeda antara petani yang menjual karet ke pasar lelang dan non pasarlelang sebagian dari petani melakukan usahatani lain dan usaha diluar usahatani sebagai tambahan pendapatan untuk memenuhi kebutuhan rumah tangga petani. Petani didaerah penelitian masih banyak yang mengusahatanikan karet saja sebagai sumber pendapatan utama yaitu sebanyak 27 petani. Petani yang melakukan cabang usahatani lain selain karet terdapat usahatani sawit, Jagung, ternak dimana untuk petani karet lelang usahatani sawit $20,6 \%$,Jagung $5,8 \%$ dan ternak $11,8 \%$.

\section{Gambaran Umum Pasar Lelang Karet dan Non lelang Karet}

Kabupaten Batanghari Kecamatan Bajubang tepatnya di Desa Penerokan dan Ladang Peris komoditi karet yang diproduksi dalam bentuk Slab Tebal. Petani di Kecamatan Bajubang khususnya untuk petani dari Desa Ladang Peris dan Penerokan menjual bahan olah karet berbentuk Slab melalui dua saluran pemasaran yaitu melalui Pasar Lelang dan Non pasar lelang. Berdasarkan penelitian di lapangan bahwa harga beli karet di Pasar lelang lebih tinggi dari harga beli karet di non pasar lelang dimana selisih harga bisa mencapai Rp.1.000- Rp.1.500. Petani yang menjual Slab ke non pasar lelang umumnya berdasarkan bobot karet bukan berdasarkan mutu atau KKK, karena mengharapkan berat karet lebih besar maka petani melakukan perendaman, mencampur lateks dengan tatal, pasir atau benda-benda lainnya sebagai penambah berat berbeda dengan penjualan Slab di Pasar lelang yang berdasarkan KKK (Kadar Kering Karet) tidak terdapat potongan (basi\%). Berdasarkan tabel 3 alasan paling banyak alasan petani melakukan penjualan di pasar lelang karena Harga dan timbangan transparan dan tidak adanya potongan basi dengan persentase $94 \%$ dan $100 \%$, sisanya $88 \%$ karena harga lebih tinggi, 91\% Harga berdasarkan mutu karet dan $100 \%$ pengawasan oleh tim.

Tabel 3. Sebaran Alasan Petani Sampel yang menjual Bokar ke Pasar Lelang di Daerah Penelitian Tahun 2019

\begin{tabular}{lrr}
\hline \multicolumn{1}{c}{ Alasan menjual dipasar lelang } & Jumlah (Orang) & Persentase (\%) \\
\hline Harga \& timbangan Transparan & 32 & 94 \\
Harga Lebih tinggi & 30 & 88 \\
Harga Sesuai Mutu (KKK) & 31 & 91 \\
Pengawasan Tim (Panitia Lelang) & 34 & 100 \\
Tidak ada Basi & 34 & 100 \\
\hline
\end{tabular}

Sumber: Olahan Data Primer (2019)

Berdasarkan tabel 4 alasan paling banyak alas an petani melakukan penjualan di non pasar lelang karena Proses penjualan cepat $100 \%$, Pembayaran langsung $92 \%$, adanya pinjaman uang $100 \%$, didatangi oleh pembeli $72 \%$, didatangi oleh penjual $28 \%$, penjualan kapan saja $89 \%$ dan pinjaman uang $100 \%$. 
Tabel 4. Sebaran Alasan Petani Sampel menjual Bokar ke Non Pasar Lelang di Daerah Penelitian Tahun 2019

\begin{tabular}{|c|c|c|c|}
\hline Alasan menjual di Non Pasar Lelang & Jumlah (Orang) & Persentase & $(\%)$ \\
\hline Pembayaran Langsung & 33 & & 92 \\
\hline Proses Penjualan Cepat & 36 & & 100 \\
\hline Didatangi oleh pembeli & 26 & & 72 \\
\hline Didatangi Oleh Penjual & 10 & & 28 \\
\hline Penjualan Kapan Saja & 32 & & 89 \\
\hline Pinjaman Uang & 36 & & 100 \\
\hline
\end{tabular}

Sumber: Olahan Data Primer (2019)

\section{Gambaran umum bahan olah karet (Bokar)}

Produksi bokar (bahan olahan karet rakyat) oleh petani di Desa pelelitian Kabupaten Batanghari berasal dari kebun milik sendiri. Petani menyadap pohon karet dimulai dari jam 06.00 sampai 10.00 , seharusnya penyadapaan dimulai pada jam 05.00 sampai jam 07.00 pagi. Semakin pagi semakin baik karena lateks lebih banyak keluar dari batang karet. . Lateks kebun yang baik merupakan syarat utama untuk mendapatkan hasil bokar yang bermutu tinggi, maka kebersihan dalam bekerja merupakan syarat yang paling utama yang harus diperhatikan oleh petani. Slab tebal adalah campuran lump mangkok dan lateks kebun yang dibekukan. Lump adalah lateks yang kebun yang dibiarkan membeku secara alamiah,untuk mempercepat proses pembekuan lateks kebun ditambahkan asam semut. Lump yang telah mengalami proses pembekuan kemudian dikumpulkan dan dimasukan kedalam cetakan serta ditambahkan lateks kebun dan segera dibekukan didalam cetakan untuk menghasilkan bahan olah karet berbenuk Slab tebal setelah itu diangkut untuk di timbang untuk dijual.

\section{Pendapatan Rumah Tangga Petani Karet}

Menurut Soekartawi (2016), pendapatan usahatani adalah selisih antara penerimaan dan semua biaya, penerimaan usaahatani adalah perkalian antara produksi yang diperoleh dengan harga jual dan biaya usahatani adalah semua biaya yang dikeluarkan dalam usahatani. Pendapatan rumah tangga dalam penelitian ini adalah pendapatan dari usahatani karet sebagai pendapatan utama, pendapatan dari luar usahatani karet yang terdiri dari usahatani Sawit, usahatani jagung, ternak yang terdiri dari ternak ayam kampung, ternak kambing dan ternak sapi.

\section{Penerimaan, Biaya dan Pendapatan}

Penerimaan adalah jumlah produksi yang dihasilkan dikali dengan harga hasil produksi. Sedangkan biaya usahatani adalah semua pengorbanan yang dikeluarkan selama proses produksi baik itu biaya yang diperhitungkan yang semula berbentuk fisik kemudian dikonversikan dengan nilai uang (rupiah) Pendapatan adalah selisih antara penerimaan dan semua biaya yang dikeluarkan selama melakukan produksi. Pendapatan dalam penelitian ini adalah pendapatan petani dalam satu tahun yang dihitung dari bulan Agustus 2018 sampai bulan juli 2019 . Sedangkan penerimaan usahatani adalah perkalian antara jumlah produksi yang diperoleh dengan harga jual. Kemudian biaya usahatani adalah semua pengeluaran yang diperlukan dalam suatu usaha ( Soekartawi,2016). Pendapatan usahatani adalah sebagai salah satu cara utnuk membandingkan biaya dan penerimaan dari proses produksi. Biaya,penerimaan dan pendapatan yang diterima petani lelang yang menjual bahan olah karet ke pasar lelang dan non pasar lelang dapat dilihat pada Tabel 5. 
Tabel 5. Perbandingan Usahatani Karet yang Menjual Bahan Olah Karet Ke Pasar Lelang dan Non Pasar Lelang Di Daerah Penelitian 2019

\begin{tabular}{|c|c|c|c|c|}
\hline \multirow[b]{2}{*}{ Uraian } & \multirow{2}{*}{$\begin{array}{c}\text { Pasar Lelang } \\
\text { Rp/Petani/Tahun }\end{array}$} & \multicolumn{3}{|c|}{ Non Pasar Lelang } \\
\hline & & Rp/Ha/Tahun & Rp/Petani/Tahun & Rp/Ha/Tahun \\
\hline \multicolumn{5}{|l|}{ A.Penerimaan } \\
\hline Produksi (Kg) & 4.638 & 1.364 & 3.573 & 1.192 \\
\hline Total Penerimaan & 45.303 .984 & 13.323 .552 & 30.604 .377 & 10.209 .480 \\
\hline \multicolumn{5}{|l|}{ B. Biaya Tetap } \\
\hline \multicolumn{5}{|l|}{ Penyusutan Alat } \\
\hline Parang & 21.441 & 6.828 & 26.813 & 8.700 \\
\hline Cetakan & 64.985 & 19.277 & 70.167 & 22.872 \\
\hline Mesin Rumput & 169.412 & 61.544 & 192.500 & 61.083 \\
\hline Kep Semprot & 195.000 & 66.199 & 215.000 & 77.146 \\
\hline Sudu & 99.185 & 28.980 & 119.900 & 39.000 \\
\hline \multicolumn{5}{|l|}{ C. Biaya Variabel } \\
\hline Pupuk & 2.414 .118 & 804.706 & 2.367 .083 & 789.028 \\
\hline Herbisida & 1.612 .353 & 474.221 & 1.695 .833 & 547.043 \\
\hline Stimulan & 643.529 & 194.961 & 1.136 .389 & 328.972 \\
\hline Cuka & 262.941 & 89.342 & 126.222 & 44.441 \\
\hline TKLK & - & - & - & - \\
\hline TKDK & 57.496 .471 & 18.935 .814 & 56.991 .111 & 20.146 .648 \\
\hline Angkutan (Transportasi) & 324.706 & 98.506 & 126.222 & 43.563 \\
\hline Total Biaya Variabel & 62.754.118 & 20.597 .550 & 62.442 .860 & 21.899.695 \\
\hline D. Total Biaya di Bayarkan & 6.227 .159 & 1.969.379 & 6.507 .097 & 23.710.971 \\
\hline E. Total Biaya di Perhitungkan & 63.723 .630 & 20.905 .193 & 63.491 .097 & 22.247 .638 \\
\hline
\end{tabular}

Sumber: Olahan Data Primer (2019)

Berdasarkan Tabel 5 dapat diketahui bahwa biaya tetap yang dikeluarkan oleh petani berbeda dimana untuk petani yang menjual karet ke pasar lelang biaya rata-rata penyusutan alat yang dikeluarkan sebesar Rp.307.643/Ha/Tahun sedangkan untuk non pasar lelang Rp.347.487/Ha/Tahun terdapat selisih biaya penyusutan alat petani disebabkan oleh berpedaan luas lahan dan jumlah alat yang dimiliki petani serta harga beli alat. Biaya pajak yang dikeluarkan oleh masing -masing petani sama Rp. 50.000/Ha/Tahun. Biaya Variabel merupakan biaya yang dikeluarkan yang jumlahnya bergantung kepada produksi yang dihasilkan atau biaya yang habis dalam satu kali proses produksi. biaya variabel yang dikeluarkan meliputi biaya pupuk, obat stimulan, pembelian cuka, pestisida, Tenaga Kerja dalam keluarga dan biaya angkutang(Transportasi). biaya variabel yang diperhitungkan petani untuk petani yang menjual bahan olah karet ke pasar lelang sebesar Rp. 63.723.629/Petani/Tahun dan Rp.20.699.588/Ha/Tahun sedangkan untuk petani yang menjual bahan olah karet ke non pasar lelang biaya variabel yang dikeluarkan Rp. 63.489.208/Petani/Tahun dan Rp.22.205.614/Ha/Tahun. Biaya pupuk merupakan biaya yang dikeluarkan untuk membeli pupuk. Pupuk merupakan salah satu faktor produksi yang penting dalam proses kegiatan usahatani karet. Penggunaan pupuk yang optimal diharapkan mampu membantu pertumbuhan tanaman dan juga meningkatkan produksi usahatani karet. Pupuk yang digunakan oleh petani karet didaerah penelitian yaitu pupuk Urea yang biasa digunakan petani dan biasanya juga petani karet jarang melakukan pemupukan. Biaya yang dikeluarkan petani dalam penggunaan pupuk oleh petani yang menjual bahan olah karet ke pasar lelang dan non pasar lelang memiliki perbedaan dimana biaya pupuk yang dikeluarkan oleh petani lelang sebesar Rp.804.706/Ha/Tahun lebih besar dibandingkan biaya pupuk yang dikeluarkan non pasar lelang Rp.789.028/Ha/Tahun. Rata -rata biaya pupuk yang dikeluarkan oleh petani yang menjual bahan olah karet lebih besar yaitu RP.2.414.118/Petani/Tahun dan petani non lelang Rp.2.367.083/Petani/Tahun.

Obat-obatan sangat berperan penting dalam kegiatan usahatani karet. Penggunaan obat-obatan sesuai seperti tempat,tepat waktu,dan tepat dosis. Penggunaan obat-obatan untuk memberantas hama dan penyakit serta pembunuhan gulma yang akan menyerang tanaman karet. Obat-obatan yang digunakan dalam penelitian ini yaitu obat herbisida dan Stimulan . Rata-rata penggunaan obatobatan pada usahatani karet 20 sampai 23 liter/Tahun dengan rata-rata penggunaan obat-obatan Rp. 2.255.882/Petani/Tahun dan Rp.683.196/Ha/Tahun dan untuk non pasar lelang 
Rp.2.832223/Petani/Tahun dan Rp.907.699/Ha/Tahun. Biaya cuka untuk pembeku lateks pasar lelang lebih besar yaitu Rp.89.342/Ha/Tahun dan non pasar lelang Rp.44.441/Ha/Tahun. Biaya penggunaan tenaga kerja pada penelitian ini merupakan biaya yang diperhitungkan karena untuk tenaga kerja petani karet menggunakan tenaga kerja dalam keluarga. Biaya lainnya dalam penelitian ini yaitu biaya angkutan atau transportasi yaitu biaya pemasaran, biaya angkut yang dikeluarkan petani lelang Rp. 324.706/Petani/Tahun dan sebesar Rp.98506/Ha/Tahun

Sedangkan untuk biaya yang dikeluarkan petani yang menjual di non pasar lelang $\mathrm{Rp}$ 133.333/Petani/Tahun dan Rp.43.563/Ha/Tahun. Biaya Produksi merupakan keseluruhan biaya yang dikeluarkan pada usahatani karet yaitu yang terdiri dari biaya tetap dan biaya variabel. Total biaya produksi merupakan keseluruhan biaya dengan menjumlahkan biaya tetap dan biaya variabel. pendapatan usahatani yang menjual ke pasar lelang lebih besar Rp. 11.846.478 dibandingkan yang menjual ke non pasar lelang Rp.8.046.025 untuk pendapatan yang diperhitungkan dalam usahatani Rp. - 7.089.336/Ha/Tahun untuk pasar lelang dan Rp. - 12.100.624 Ha/Tahun untuk non pasar lelang. Dengan total biaya variabel dan biaya tetap Rp.1.969.379/Ha/Tahun dan Rp.6.227.199/Petani/Tahun sedangkan untuk pasar lelang dan Rp.2.100.990/Ha/Tahun Rp.6.507.097/Petani/Tahun untuk non pasar lelang. Adapun biaya usahatani yang diperhitungkan Rp.63.723.630/Petani/Tahun dan Rp.20.905.193/Ha/Tahun untuk pasar lelang dan RP.63.491.097/Petani/Tahun dan RP.22.247.637/Ha/Tahun.

\section{Analisis Perbandingan Pendapatan Kerja Utama Usahatani karet Petani Karet dan perbandingan pendapatan petani karet yang Menjual Bahan Olah Karet Ke Pasar Lelang dan Non Pasar Lelang}

Perbedaan pendapatan antara petani yang menjual bahan olah karet ke pasar lelang dan non pasar lelang disebabkan oleh perbedaan biaya yang dikeluarkan petani baik biaya variabel mapun biaya tetap. Adapun uji beda dua rata-rata Pendapatan kerja utama usahatani karet yang menjual bahan olah karet ke pasar lelang dan non pasar lelang.dapat dilihat pada tabel 6 .

Tabel 6. Perbandingan Pendapatan Petani Karet yang Menjual Bahan Olah Karet Ke Pasar Lelang dan Non Pasar Lelang Di Daerah Penelitian 2019

\begin{tabular}{clrr}
\hline No. & \multicolumn{1}{c}{ Uraian } & Pasar Lelang & \multicolumn{2}{r}{ Non Pasar Lelang } \\
\hline & & 34 & 36 \\
& Jumlah Sample $(\mathrm{N})$ & & 8.046 .025 \\
2 & Rata-rata Pendapatan (Mean) & 11.846 .478 & 0.000 \\
3 & Sig (2 tailed) & 0.000 & \\
\hline
\end{tabular}

Sumber: Olahan Data Primer (2019)

Berdasarkan Tabel 6 pendapatan antara petani yang menjual bahan olah karet ke pasar lelang dan non pasar lelang menunjukkan bahwa nilai sig 2 tailed $<\alpha=5 \% 0,005$, dimana diperoleh nilai sig( 2 tailed) sebesar 0,000 lebih kecil dari nilai $<\alpha=5 \%$ yang berarti terdapat perbedaan pendapatan usahatani responden yang menjual bahan olah karet ke pasar lelang dan non pasar lelang (terima $\mathrm{H} 1$ tolak $\mathrm{H} 0$ ) dengan $\mathrm{t}$ hit $>\mathrm{t}$ table yaitu $10,453>1,669$. Adanya perbedaan pendapatan ini dikarenakan pendapatan usahatani yang menjual ke pasar lelang lebih besar Rp. $11.846 .478 / \mathrm{Ha} /$ Tahun dibandingkan yang menjual ke non pasar lelang Rp.8.046.025/Ha/Tahun. . Untuk pendapatan rumah tangga petani karet lelang sebesar Rp. 48.947.782/Tahun dan non pasar lelang Rp. 20.215.179/ Tahun dapat dilihat pada tabel 7.

Tabel 7. Perbandingan Pendapatan Petani Karet yang Menjual Bahan Olah Karet Ke Pasar Lelang dan Non Pasar Lelang Di Daerah Penelitian 2019

\begin{tabular}{clrr}
\hline No. & \multicolumn{1}{c}{ Uraian } & Pasar Lelang & Non Pasar Lelang \\
\hline 1 & Jumlah Sample (N) & 34 & 36 \\
2 & Rata-rata Pendapatan (Mean) & 48.947 .782 & 20.215 .179 \\
3 & Sig (2 tailed) & 0.000 & 0.000 \\
\hline
\end{tabular}

Sumber: Olahan Data Primer (2019) 
Berdasarkan Tabel 7 pada tingkat kepercayaan 95\% dapat dilihat bahwa hasil uji beda dua rata-rata pendapatan antara petani yang menjual bahan olah karet ke pasar lelang dan non pasar lelang menunjukkan bahwa nilai sig 2 tailed $<\alpha=5 \% 0,005$, dimana diperoleh nilai sig( 2 tailed) sebesar 0,000 lebih kecil dari nilai $<\alpha=5 \%$ yang berarti terdapat perbedaan pendapatan rumah tangga petani karet yang menjual bahan olah karet ke pasar lelang dan non pasar lelang (terima $\mathrm{H} 1$ tolak $\mathrm{HO}$ ) dengan selisih pendapatan rumah tangga sebesar Rp. 20.215.179/Tahun dengan $t$ hit $>t$ table yaitu $6,34>1,67$.

\section{Pendapatan Usahatani Karet, Luar Usahatani Karet dan Non Usahatani}

Pendapatan rumah tangga petani di daera penelitian memiliki sepuluh pola yaitu pendapatan yang hanya berasal dari usahatani karet saja, pendapatan karet dengan sawit, pendapatan karet dengan jagung, pendapatan karet dengan ternak dan pendapatan karet dengan non pertanian seperti buruh, bangunan, perangkat desa, warung dan guru. pendapatan petani tertinggi adalah pada pola ke VII yaitu Rp. 83.102.604/Tahun dengan mengusahakan Karet + usaha warung/toko selanjutnya diikuti dengan usahatani karet + usahatani sawit pola II yaitu Rp.71.636.158/Tahu serta pola IV Rp. 57.267.364 pola VI Rp.39.743.225. Jika petani hanya mengandalkan usahatani karet sebagai sumber pendapatan, maka pendapatan yang diterima petani sebesar Rp. 31.027.673/Tahun yang merupakan pendapatan petani karet baik yang menjual bahan olah karet ke pasar lelang maupun non pasar lelang. Pendapatan rumah tangga rata-rata yang diterima petani adalah sebesar Rp. 38.548.547/Tahun.

\section{Distribusi Pendapatan}

Distribusi pendapatan merupakan ukuran yang digunakan untuk menunjukan tingkat pemerataan pendapatan yang diterima oleh masyarakat. Distribusi pendapatan adalah konsep yang lebih luas dibanding kemiskinan karena cangkupannya tidak hanya menganalisa populasi yang berada dibawah garis kemiskinan. Kebanyakan dari ukuran tingkat distribusi pendapatan tidak bergantungpada rata-rata distribisi, karena membuat ukuran distribusi pendapatan dipertimbangkan lebih lemah dalam menggambarkan tingkat kesejahteraan. Pertumbuhan ekonomi mengandung pengertian proses kenaikan perkapita dalam jangka panjang atau perubahan tingkat kegiatan ekonomi yang terjadi dari tahun ke tahun. Pertumbuhan ekonomi yang tinggi akan menjadi kurang berarti jika terdapat ketimpangan pendapatan yang cukup tinggi, karena jika pertumbuhan ekonomi yang tinggi disertai dengan distribusi pendapatan yang tidak merata (Ketimpangan tinggi), mencerminkan sebagian pendapatan dinikmati oleh sebagian kecil penduduk (golongan berpendapatan rendah) menikmati sebagian kecil pendapatan daerah. Jika kondisi ini dialami oleh suatu daerah, menandakan tingginya tingkat kemiskinan didaerah tersebut.

\section{Distribusi Pendapatan Utama Usahatani Karet dan Pendapatan Petani Karet (Indeks Gini Rasio satu kawasan/wilayah)}

Angka Indeks Gini Rasio petani berdasarkan pendapatan utama dari usahatani karet dengan tingkat ketimpangan rendah sebesar, 0,29 artinya distribusi pendapatan berada dalam ketimpangan rendah. Kurva Lorenz dapat memperlihatkan hubungan kuantitatif actual antara presentase penerimaan pendapatan dan presentase pendapatan total yang benar-benar mereka terima. Semakin jauh jarak kurva Lorenz dari garis diagonal (yang merupakan garis pemerataan sempurna), maka semakin timpang atau tidak merata distribusi pendapatannya. Sebaliknya, jika kurva semakin dekat dari garis diagonal maka distribusi pendapatan semakin merata. 


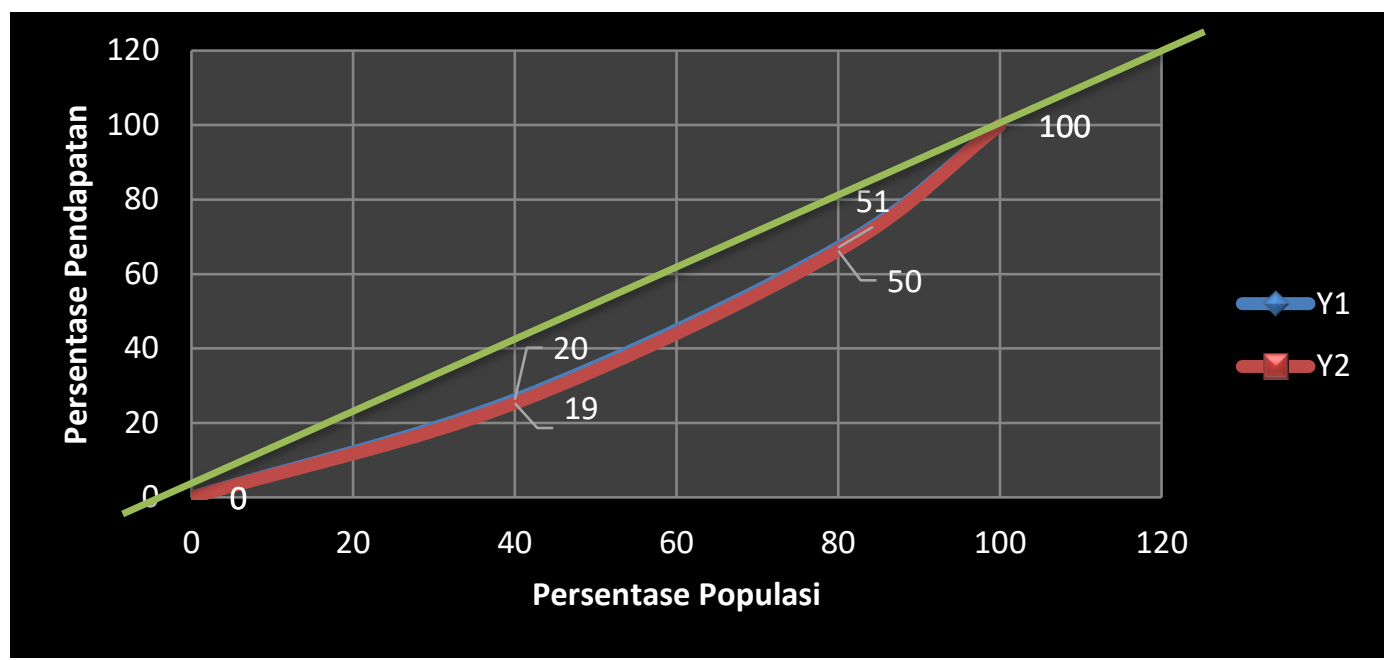

Ket: Y1 : Pendapatan Utama Karet Pasar Lelang dan Non Pasar Lelang

Y2 : Pendapatan Rumah Tangga (Pendapatan Petani Karet)

Gambar 1 . Kurva Lorenz Distribusi Pendapatan Satu Kawasan/Wilayah

Petani yang memiliki tanaman karet yang produktif dalam jumlah yang luas akan memiliki pendapatan relative tinggi dibandingkan petani yang memiliki luas lahan karet sedikit, semakin timpang kepemilikan lahan karet yang produktif maka akan semakin tinggi ketimpangan dalam distribusi pendapatan. Besarnya Indeks Gini Rasio pendapatan petani karet sebesar 0,32 berada pada ketimpangan sedang. Nilai tersebut berbeda jika dibandingkan dengan nilai indeks gini rasio pendapatan dari usahatani karet saja $(0,29)$ dalam ketimpangan rendah. Nilai indeks gini pendapatan petani karet yang lebih tinggi dikarenakan perbedaan dalam luas usahatani yang dimiliki serta adanya variasi pekerjaan sampingan rumah tangga petani karet.

Angka Indeks Gini Rasio petani berdasarkan pendapatan utama dari usahatani karet. Tingkat ketimpangan rendah sebesar, 0,27 artinya distribusi pendapatan berada dalam ketimpangan rendah. Dimana petani yang menjual bahan olah karet kepasar lelang yang menyatakan bahwa tingkat kesenjangan rendah. Adapun pendapatan petani karet dengan nilai indeks ginisama yaitu 0,27 yang berada pada ketimpangan rendah menunjukkan sebaran distribusi pendapatan penduduk disetiap lapisan rumah tangga petani karet merata, artinya tingkat kesenjangan distribusi pendapatan petani karet rendah. Kurva diatas juga menjelaskan bahwa ketika petani hanya mengandalkan satu sumber pendapatan utama yaitu pendapatan karet ketimpangan pendapatan yang terjadi untuk petani yang menjual bahan olah karet ke pasar lelang adalah 0,27.

Nilai indeks gini rasio pendapatan utama karet 0,24 yang berada pada ketimpangan rendah. Adapun nilai Indeks Gini Rasio petani karet petani karet yang menjual bahan olah karet ke non pasar lelang $0,26>$ dari Indeks Gini Rasio pendapatan utama. Perbedaan yang didapat tidak terlalu jauh masih berada pada ketimpangan rendah dengan ketentuan $<0,3$. Nilai indek gini pendapatan petani karet lebih besar dikarenakan perbedaan luas lahan yang dimiliki dan sumber sumber pendapatan tambahan petani. Dimana lebih besar pendapatan petani karet perlunya pemerataan untuk memperkecil nilai indeks gini rasio pendapatan rumah tangga non pasar lelang dengan lebih banyak memasarkan ke bokar ke pasar lelang. sebaran distribusi pendapatan penduduk disetiap lapisan rumah tangga petani karet merata, artinya tingkat kesenjangan distribusi pendapatan petani karet rendah. Kurva diatas juga menjelaskan bahwa ketika petani hanya mengandalkan satu sumber pendapatan utama yaitu pendapatan karet ketimpangan pendapatan yang terjadi untuk petani yang menjual bahan olah karet ke non pasar lelang adalah 0,24.Namun ketika melakukan kegiatan usahatani luar karet dan usaha sampingan ketimpangan pendapatan yang terjadi sebesar 0,26 maka akan semakin lebih merata jika petani tidak hanya mengandalkan satu sumber mata pencaharian saja yaitu usahatani karet petani bisa menambah sumber pendapatan lainnya..

Indeks Gini Rasio menjelaskan bahwa ketika petani hanya mengandalkan satu sumber pendapatan utama yaitu pendapatan karet ketimpangan pendapatan yang terjadi untuk petani yang menjual bahan olah karet ke pasar lelang adalah 0,27 dan petani yang menjual bahan olah karet ke non pasar lelang adalah 0,24 . hal ini dikarenakan masih lebih merata nya pendapatan petani yang menjual di non lelang dari pada petani yang menjual dipasar lelang disebabkan lebih banyaknya petani yang menjual bahan olah karet ke non pasar lelang dibandingkan ke pasar lelang padahal pendapatan 
yang di dapat dari dua saluran pemasaran tersebut berbeda dimana untuk yang menjual ke lelang paling rendah pendapatan yang diterima Rp.23.253.286/Petani/Tahun atau Rp.8.587.328/Ha/Tahun dan Non lelang Rp.11.999.958/Petani/Tahun atau Rp.5.515.647/Ha/Tahun. Dengan perbedaan pendapatan yang diterima untuk itu petani membutuhkan sumber pendapatan lain untuh menambah dan memenuhi kebutuhan rumahtangga petani karet. Namun ketika melakukan kegiatan usahatani luar karet dan usaha sampingan ketimpangan pendapatan yang terjadi sebesar 0,27 untuk petani lelang dan 0,26 untuk petani non lelang maka akan semakin lebih merata jika petani tidak hanya mengandalkan satu sumber mata pencaharian saja yaitu usahatani karet petani bisa menambah sumber pendapatan lainnya.

\section{KESIMPULAN}

Rata-rata pendapatan rata-rata petani yang menjual bahan olah karet ke pasar lelang sebesar Rp. 11.846.478/Ha/Tahun dan non pasar lelang sebesar Rp.8.046.025/Ha/Tahun dengan selisih pendapatan $\mathrm{Rp}$. 3.800.453/Ha/Tahun berbeda nyata dengan tingkat kepercayaan $95 \%$ pada uji test dapat dilihat bahwa hasil uji beda dua rata-rata pendapatan antara petani yang menjual bahan olah karet ke pasar lelang dan non pasar lelang menunjukkan terdapat perbedaan pendapatan utama petani karet yang menjual bahan olah karet ke pasar lelang dan non pasar Pendapatan Rumah Tangga Petani karet yang menjual bahan olah karet ke pasar lelang dan non pasar lelang memiliki perbedaan pendapatan, Berdasarkan hasil uji beda dua rata-rata pendapatan rata-rata petani yang menjual bahan olah karet ke pasar lelang sebesar Rp. 48.947.782/Tahun pendapatan rumah tangga petani karet yang menjual bahan olah karet ke pasar lelang dan non pasar lelang thit $>$ ttabelyaitu $6,34>1,67$ (terima $\mathrm{H} 1$ tolak H0). Nilai Indeks Gini pendapatan utama usahatani karet yaitu 0,29 untuk $<0,32$ untuk pendapatan petani karet, untuk lebih memperkecil nilai indeks gini maka dengan menambah sumber-sumber pendapatan lainnya yang tidak bergantung pada usahatani karet saja. Distribusi pendapatan utama petani karet yang menjual bahan olah karet ke pasar lelang dan ke non pasar lelang cukup merata dengan angka Indeks Gini Rasio 0,27 untuk petani karet pasar lelang > 0,24 untuk petani karet non pasar lelang dan tingkat ketimpangan pendapatan rendah.

\section{DAFTAR PUSTAKA}

Afriyani. 2015. Struktur dan Distribusi Pendapatan Petani Kelapa Sawit Pola PIR di Desa Mekar Jaya Kecamatan Kampar Kiri Tengah Kabupaten Kampar. Jurnal.2 (1) 1-13. Jurnal ilmiah Fakultas Pertanian Universitas Riau. Riau

Badan Pusat Statistik.2018. Statistik Indonesia. Jakarta : BPS Direktorat Jendral Perkebunan. 2017. Statistik Perkebunan Indonesia. Situs Direktorat Jendral Perkebunan. Diunduh dari http://www.dirjenbun.go.id/statis perkebunan.html. (Diakses 10 Februari 2019). Jambi 2016.Provinsi Jambi.

Jambi 2011.Provinsi Jambi.

2017. Statistik Tanaman Perkebunan Provinsi

2017. Statistik Perkebunan Kabupaten Batanghari 2017

Provinsi Jambi.

BP3K Kecamatan Bajubang.2018. Luas Lahan,Produksi dan Produktivitas Karet,Batanghari.

Frianto, Agus Manik. 2016. Distribusi Pendapatan Rumah Tangga Petani Karet EKS UPP TCSDP dan swadaya di Desa Bina Baru Kecamatan Kampar Kabupaten Kampar. Jurnal.3 (2), 1-12. Jurnal ilmiah Fakultas Pertanian Universitas Riau. Riau

Frisna. 2017. Distribusi kelapa sawit pola KKPA di Desa Bina Baru Kecamatan Kampar Kiri Tengah Kabupaten Kampar. Jurnal. 8 (1) 62-80. Jurnal ilmiah Fakultas Pertanian Universitas Riau. Riau.

Gitosurdarmo, Indriyo. 1983. Manajemen Pemasaran. BPFE Yogyakarta.Yogyakarta.

Gustiana,Emalia. 2017. Analisis Pendapatan dan Distribusi Pendapatan Usahatani TebuRakyat di Kecamatan Bungamayang Kabupaten Lampung Utara. Skripsi Agribisnis Fakultas Pertanian. Universitas Lampung. Bandar Lampung.

Harry. 2013. Koperasi Pertanian. Penerbit Alfabeta. Bandung.

Hernanto. F. 1996. IImu Usahatani. Penebar Swadaya, Jakarta.

Hendrojogi,2002. Koperasi : Azas-azas teori dan praktek koperasi. Cetakan pertama.PT Rineka Cipta. Jakarta.

Marlian dan Djauhari, 1999. Teknologi Pengolahan Petani. BPFE Yogyakarta.Yogyakarta. 
Nayuna, M. 2005. Beberapa Faktor Sosial Ekonomi yang Mempengaruhi Produksi, Produktivitas dan Pendapatan Bersih Usahatani Karet Rakyat di Kabupaten Asahan. Skripsi. Universitas Sumatera Utara, Medan.

Pedoman Penulisan Karya IImiah.2010 Fakultas Pertanian. Universitas Jambi.Jambi

Peranturan Menteri Pertanian No. 38/permentan/OT.140/8/2008 tentang pedoman pengolahan dan pemasaran Bahan Olah Karet (bokar). ( Diakses pada 29 Mei 2019).

Pranata, Yudi. 2018. Pendapatan dan Tingkat Kesejahteraan Rumah Tangga Petani Lada di Kecamatan Tanjung Raja Kabupaten Tanjung Utara. Skripsi Agribisnis Fakultas Pertanian. Universitas Lampung. Bandar Lampung

Reksohadijprodjo,soekanto dan Hani Handoko.1998. Organisasi Perusahaan, Teori, Struktur dan Prilaku. BPFE.Yogyakarta.

Riduwan dan Akdon.2008.Rumus dan Data dalam Aplikasi Statistika.Alfabeta.Bandung.

Sadjad S. 1983. Empat Belas Tanaman Perkebunan Untuk Agroindustri.PN Balai Pustaka.Jakarta

Soekartawi. 2016. AnalisisUsahatani. Universitas Indonesia Press, Jakarta.

Subandi.2010. Ekonomi Koperasi : Teori dan Praktek. Bandung. Penerbit Alfabeta. Bandung.

Sugiyono,2005.Metode Penelitian Administrasi. CV.Alfabeta. Bandung

Sugiyem.2015. Kajian Pendapatan Usahatani Karet yang menggunakan stimulan dan non stimulan di Kecamatan Pelepat ilir Kabupaten Bungo. Jurnal Penelitian Fakultas Pertanian Universitas Jambi. Jambi.

Sujarweni, V. Wiratna. 2014. Metodologi Penelitian. Yogyakarta: Pustaka Baru Press.

Sukirno, Sadono.2007. Pengantar Teori Mikroekonomi. Raja Grafindo Persada Jakarta

Sulastri, Afriadi. 2007. Pedagang Pengumpul desa. Jurnal Penelitian Ekonomi. Univeritas Padjajaran.

Suratiyah.2015.IImu Usahatani. Penebar Swadya. Jakarta.

Surwadin, Didin. 1997. Karateristik Mutu Karet Alam SIR. Jurnal Pusat Penelitiam Karet. Sumbawa.

Suseno Triyanto Widodo. 1990. Indikator Ekonomi. Peneribit Kanisius. Yogyakarta

Syahza A. 2003. Percepatan peningkatan Ekonomi Pedesaan Melalui Koperasi Berbasis Agribisnis di Daerah Pedesaan. Jurnal Penelitian Ekonomi. Univeritas Padjajaran.

Todaro, M.P. 2003. Pembangunan Ekonomi di Dunia Ketiga. Penerbit Erlangga. Jakarta

Triyanto S. 1990. Indikator Ekonomi. Penerbit Kanisius. Yogyakarta.

Widodo.1990. Ekonomi Indonesia dalam Era Liberisasi. Penerbit Kanisius. Yogyakarta.

Wulandari,Niken .2017. Ketergantungan petani pada tengkulak dalam pemasaran karet di kabupaten Batanghari. Jurnal Penelitian Fakultas Pertanian Universitas Jambi. Jambi. 